Lucrările Seminarului Geografic Dimitrie Cantemir

Vol. 45, October 2017, pp. 203-215

http://dx.doi.org/10.15551/lsgdc.v45i0.17

\title{
Europe and Caspian energy projects. A new way to approach Europe's energy security
}

\section{Silviu Marius Suditu ${ }^{1}$}

${ }^{1}$ University of Bucharest, Romania

To cite this article: Suditu, S.M. (2017). Europe and Caspian energy projects. A new way to approach Europe's energy security. Lucrările Seminarului Geografic Dimitrie Cantemir, Vol. 45, pp. 203-215. DOI: $10.15551 /$ lsgdc.v45i0.17

To link to this article: http://dx.doi.org/10.15551/lsgdc.v45i0.17 


\title{
EUROPE AND CASPIAN ENERGY PROJECTS. A NEW WAY TO APPROACH EUROPE'S ENERGY SECURITY
}

\author{
Silviu Marius Suditu ${ }^{1}$
}

\begin{abstract}
Ayant un passé tumultueux et un présent aussi agité, la région caspienne a attiré l'attention des européens depuis quand les États riverains ont obtenu l'indépendance de URSS. Mais après la crise de l'Ukraine, l'Europe a commencé à conscientiser sa profonde dépendance des ressources russes et particulièrement de Gazprom, société que les Russes, plusieurs fois l’ont utilisé comme une arme. Ainsi que la région caspienne, riche en gisements de pétrole et gaz naturels est devenue une vraie alternative de l'Europe pour les ressources russes. Tout au long de temps, plusieurs sociétés multinationales ont amplifié les relations avec les états caspiennes et ont démarré des importants projets d’infrastructure énergétique. Mais, le chemin de l’énergie caspienne vers l'Europe a été très difficile, marqué par beaucoup de projets bloqués, ajournés ou abandonnés. Malgré cela, plusieurs projets pour les gazoducs et les oléoducs ont été démarré et d’autres sont au cours de finalisation. Des projets comme BTC, TANAP ou South Stream sont quelques exemples que la sécurité énergétique peut être obtenue avec des avantages pour les deux parts. Les ambitions du vieux contient de passer à une économie moins polluante, vont s`appuyer dans le futur sur les énergies qui se régénèrent, mais pour une transition plus simple et qui ne périclite pas l'élan économique on a encore besoin des sources d`énergies traditionnels. La solution du règlement juridique de la Mer Caspienne, une image commune des pays de l'Union Européen et l’orientation de l’attention sur les États de la zone plus large de la Mer Caspienne, comme potentielles sources, sont quelques solutions que l'Europe les a pour diversifier l’origine des ressourcés si fondamentaux pour l'économie.
\end{abstract}

Keywords: Mer Caspienne, pipeline, ressourcés, infrastructure énergétique, alternative

\section{Introduction}

Because of its geographical position, the Caspian region has had a multitude of barriers regarding a sustainable development in both oil and gas sector. During the communism, the Caspian Region was considered to be only a small part of the great USSR, therefore there was absolutely no interest in building pipelines to connect the Caspian Sea with Europe. After the collapse of the USSR, Caspian countries hoped for a stable economy, driven by the export of gas and oil to the Western market. But this was possible only by building a pipeline network that could connect them to the developed countries in Europe, avoiding Russian pipelines. After 1990 some great companies showed their interest in building pipelines in order to transport gas and oil from the South Caucasus, but the countless conflicts that shook the area, corroborated with the 2008 financial crisis were important obstacles.

\footnotetext{
${ }^{1}$ Doctoral School Simion Mehedinți, Faculty of Geography, Bucharest University, suditu.silviu@yahoo.com
} 
The East-West Corridor raises many environmental and security issues. Regarding the environment, the main issue is the necessity of crossing the Black Sea and the Mediterranean Sea, throw the Bosphorus, which could produce real environmental disaster. There are also a lot of security problems. The transport of Caspian energy raises hegemonic claims from Russia, which considers the Caucasian countries part of its traditional sphere of influence. Turkey faces the secessionist claims of the Kurdish minority, and the authoritarian regime ruled by Erdogan have moved away Turkey from the main Western values. Iran faced US sanctions for several years, Azerbaijan is in very tense relationship with its neighbor Armenia, Georgia entered into conflict with Russia as a result of the secessionist claims of the Ossetians, and Ukraine faces political and economic instability as a result of misunderstandings with Russia. All this adds to the wars in Iraq and Afghanistan.

According to Eurostat, in 2015, Europe imported 282 billion cubic meters of natural gas, and for 2020 the consumption is estimated to reach 400 billion cubic meters. Following the Ukrainian crisis in 2014, the western countries had become more concerned with the energy security issue. So, states and companies located both in Europe and in the US have become more and more interested in the fate of projects started in the Caucasus region.

Some projects have been intensively publicized and still remained without investors, others were a real success. However, after their construction a new question has been raised, if the Caspian countries had the capacity to quantitatively support the European energy needs. Estimates made in the early 1990s were regarding the amount of oil and natural gas in the Caspian region, were rather unrealistic. The idea that the Caspian region could have similar reserves to the Persian Gulf, was far from the truth. Even so, the area remained one of maximum interest and helps European Union to take important steps toward energy independence from Russia. The start was given by the Americans who, due to their great influence in the Caspian region after the dissolution of the USSR, had financially and logistically supported the construction of the first pipelines. They were designed to avoid conflict zones as much as possible, but especially as a southern alternative to Russian pipelines. They were passing through friendly states such as Turkey and avoiding hostile states like Iran.

After the collapse of Soviet Union, there was a new reality in the Caspian Region. There were five bordering nations on the Caspian's shores: in the southwest Azerbaijan, in the south Iran, in the northeast Kazakhstan, in the southeast Turkmenistan and in the northwest Russia. So these five countries were forced to solve the main important problem in the region: legal status of the Caspian. So they needed to answer the question: lake or a sea? Although the five seaside states have failed to understand one with each other about the Caspian Sea legal status, which also kept their economic development on track, progress has been made in the last years, with a few shady investments in infrastructure. Having the main western actors on the energy market, support and as much as new fields are being discovered, states such as Azerbaijan and Kazakhstan, begun a series of bold energy projects.

The easiest solution for Caspian oil and gas would have been to build a pipeline to pass through Iran and deliver to the Asian market, but this idea hit the opposition of US and European Companies policy, which would never finance such a project. The reason simple, the increasing demand from the European market and its desire to find an alternative to Russia and the Middle East. In 2000 Europe imported 75\% of the total oil demand, while in 
2010 the percentage grew by $84 \%$, the main sources being Russia and OPEC, Iran, Saudi Arabia and Libya.

Therefore the 1990s ware marked by the idea of developing the hydrocarbon transport infrastructure. First steps in Azerbaijan's case, for example, were traditionally made to Russia, with the construction of the Baku-Novorossiysk oil pipeline, also known as the Nordic Route. It links the Baku capital to the Russian port of Novorossiysk. It has 1330 kilometers, is divided between Gazprom and SOCAR and was inaugurated on April 17, 1999. For Azerbaijan it was a real success to build this pipeline because, for the first time, Azeri oil could easily be transported to the world markets at infinitely lower costs than ever before. However, Baku-Novorossiysk pipeline has confronted with the political instability in the Caucasus. Thus, in the initial plans, the pipeline was passing through the capital of Chechen, Grozny, which stopped oil transport in 1999. Oil was loaded before it arrived in the Chechen-controlled territory in wagons and then transported to Danhestan. After Russia attacked Chechnya, Transneft built a bypass route that completely avoided the war zone.

\section{Main oil pipelines from the Caspian Region to the EU}

In order to minimize dependence on the Russian giant, the Caspian countries have considered constructing pipelines in a different direction than the traditional one. So they have developed projects from east to west with the desire to get as close as possible to the European market. Thus, the Azeri authorities began to look for alternatives for the northern route, taking into account the transport of oil through Georgia to the Black Sea. Therefore an agreement was signed between the Presidents of Azerbaijan and Georgia on 8 March 1996 in Tbilisi. The pipeline called Baku-Supsa became operational three years later, and the first transport was in 1999. Azerbaijan's transportation costs to the Russian port reached \$15.67, while the Supsa price was just $\$ 13.14$. This is also the reason why the efficiency of the Nordic route Baku-Novorossiysk has often been contested.

The Caspian Pipeline Consortium Project links Tengiz field, Kazakhstan to the Black Sea coast of Novorossiysk, Russia, and then, it is transported by sea, via the Bosphorus Strait to the Mediterranean Sea. Russia opposed this pipeline project, because it had created an alternative to Kazakhstan, undermining Russia's monopoly in Europe. However the project continued due to the influence of the United States in the area which was greater, despite the geographic advantage owned by Russia, therefore the pipeline was built and put to use despite Moscow's opposition.

On the other hand, Turkey did not approved the construction of this pipeline, Turkish authorities said that they are concerned about the capacity of the Bosphorus to bear a even more intense traffic. Turkey's opposition was not totally unfounded, since the environmental issue and the protection of the marine environment in the Black Sea is a real one. Beyond that, Turkey has seen the opportunity to win something from this, taking advantage of its geographical position. Therefore, invoking marine environment that could have suffered as a result of possible oil or gas pollution, Turkish authorities had a successful lobby in order to build a new pipeline through its territory to a port directly linked to the Mediterranean Sea, avoiding the Black Sea and the world's most intensely used strained. And since European countries are dependent mainly on Russian gas, but also on oil, Turkey has become the favorite. Being able to take a real advantage of its geographical position and good external relations with the Western world, Turkey has become Europe's alternative to Caspian energy transport. 
In 1992, Turkish Prime Minister, Suleyman Demirel, proposed to the states of Central Asia and Azerbaijan the construction of a pipeline to transport Caspian oil to Europe through the Turkish territory. At the time, there were negotiations regarding an agreement between Azerbaijan, Armenia and Turkey, but between Azerbaijan and Armenia a war broke out in Nagorno Karabakh region. Therefore the external relationship between the two stopped and made it impossible for the two states to cooperate. In 1998, before the signing ceremony of the building agreement, the US Secretary of Energy said the pipeline was one of national interest to Americans.

The Baku-Tbilisi-Ceyhan pipeline became reality in 2002 and begun to operate at full capacity in 2006, generating large gains for both Turkey and Georgia, transit states. The pipeline has $1768 \mathrm{~km}$ and connects Baku, Azerbaijan's capital, Tblisi, the capital of Georgia and the Mediterranean port of Ceyhan in Turkey. On Azeri land, the pipeline passes just a few kilometers from the Nagorno-Karabakh enclave, which has caused a series of fears about a possible terrorist attacks. If for Azerbaijan the pipeline was extraordinary from an economic point of view, its construction only deepened the isolation of Armenia. For Georgia, it was also an important step in the process of gaining energy independence from Russia and continuing its orientation towards Western structures.

Since the construction and commissioning of the BTC pipeline it has been a real success for both Europeans and Americans, representing a first real step in achieving EU energy security, despite the fact that it only provides $1.5 \%$ of the oil demand. The silk road of the 21st century was a source of inspiration for other projects.

In March 2005, Azerbaijan and Kazakhstan decided to build an oil pipeline to connect an offshore basin near the Kazakh city of Aktau with the rest of the BTC pipeline. In April 2007, an agreement was signed in Astana between the Kazakh state gas company Gaz Munay Gaz, the Tengiz Group and several private companies that showed their interest to the project. However, the pipeline did not pass the project stage because of the uncertain legal status of the Caspian Sea. As a result, Kazakh oil has been shipped to the Azeri shore.

In 1997 there were multiple discussions of a silk road, in terms of Caspian oil. In order to avoid the use of the Bosporus and Dardanelles, the oil from the Caspian Sea and Russia would have arrived by sea at Constanța, Romania. Afterword it would have been transported by a pipeline to Trieste, Italy. Known as PAN European Oil Pipeline, the project would have crossed five countries, Romania, Serbia, Croatia, Slovenia and Italy. The pipeline should have had 1360 kilometers and the costs would have amounted 4.26 billion dollars. In 2009, the project also gained the interest of Azerbaijan, which has expressed its desire to sustain natural gas and oil deposits on Romania's territory, to invest in the PEOP pipeline, but also to be a constant supplier for it. Despite that, only two years later Croatia, Italy and Slovenia withdrew, and the only interested countries Romania and Serbia decided to use a different route, Pitesti-Pancevo. Subsequent, Romania has liquidated the project company and the ambitious PAN-European Oil pipeline has been abandoned.

Although since 2014 nobody has spoken or discussed about the project, in 2017 Serbia and Romania have brought to light the oil project. Conpet, National Oil Transportation Company of Romania started discussions with several investors, including Oil Terminal Constanta, company that have been involved in the first phase of the project. 


\section{Crossing the Caspian. Main gas pipelines.}

The boldest project launched by the European Union states to reduce European Union states dependence on Russian gas imports was NABUCCO. It would have been 3000 kilometers long and would have transported Azerbaijan and Turkmenistan gas to Europe through Turkey, Bulgaria, Romania, Hungary and Austria.

First discussions took place in February 2002, then a memorandum for the construction of the pipeline was signed in July. At the end of 2013, the European Commission itself granted $50 \%$ of the amount needed to make the feasibility study. This was a strong signal that the Europeans are willing to support the project. In 2009, the first agreement was signed between source and transit states. However, funding was a major problem for the Nabucco gas pipeline. Even though the European Investment Bank and the Reconstruction and Development Bank have announced that they will support the consortium through advantageous loans, the project was rejected by the General Affairs and External Relations Council of the European Union. Only a few days later, after intense negotiations between Europeans and the states that were to be transited by the gas pipeline, the project received an initial funding of 200 million euros.

The costs were estimated at $€ 7.9$ billion, hence the project has been hit by the failure of European firms to invest in such a costly project, in the context of the financial crisis and the uncertainty of overcoming it. Nabucco would have had a capacity of 31 billion cubic meters of gas. In 2011, Turkey and Azerbaijan announced that they plan to build a new gas pipeline to transport resources from the Caspian Sea through Turkey, to Greece.

This project, from the start, transited fewer states and cost less than Nabucco. As a result, the Nabucco project was modified, at a much smaller scale, and it became NabuccoWest. This project was meant to involve fewer countries, such as Bulgaria, Romania and Hungary. The Nabucco West gas pipeline should have been connected to the natural gas from the TANAP pipeline. It would have delivered for the first time in 2018. But the British gas giant operating company from Shah Deniz chose another project, the Trans Adriatic Project, to Italy via Greece and Albania.

In 2013, despite the political support, Nabucco was abandoned. Three factors contributed decisively to the closure of the Nabucco project, the limited demand for gas on short term from the European Union that was recovering from the financial crisis, the construction costs that were too high and the competition from other projects such as the South Stream gas pipeline, TANAP or the Trans-Adriatic pipeline.

After the 1999 discoveries of the Shah Deniz deposit, the Azerbaijan and the neighboring countries have begun several negotiations to build a gas pipeline to facilitate natural gas exports to Georgia and Turkey. The pipeline has a $980 \mathrm{~km}$ length and runs parallel to the BTC pipeline to Erzurum in Turkey. The pipeline should be completed in 2020 and it will reach a full capacity of 16 billion cubic meters of natural gas each year. 6 billion cubic meters are already contracted by Turkey as a transit state, which means that Europe will only have 10 million cubic meters. The volumes transported are modest compared to those reported in the NABUCCO project. The small volume of natural gas to be transported through the Southern Corridor has raised serious concerns on the European side, which has attempted to diversify its gas sources, taking into consideration the possibility of connecting to the pipeline other states too, including Turkmenistan or Iran. However, the import from Turkmenistan can only be through a pipeline that would transit through the Caspian Sea, which is almost impossible due to the uncertainty situation in the Caspian Sea. 
Because of restrictive policies that discourage foreign investors, Turkmenistan does not have the capacity of exporting in the EU. And Iran faces a lack of infrastructure, corroborated with the international sanctions because of the nuclear program. These sanctions have slowed down the gas infrastructure in Iran, mainly because foreign investors avoided Iranian projects. But, at the moment there are some pipelines that connect Turkmenistan to Iran. These could serve to pipe gas to the European Union using the Turkey route, but for this to happen is necessary a strong goodwill on both sides.

The idea of building a gas pipeline to facilitate the transport of natural gas from Caspian Sea to Europe materialized in 2012, when Azerbaijan and Turkey decided to build a gas pipeline known as Trans Anatolian Natural Gas Pipeline (TANAP). The TANAP gas pipeline is supposed to be a substitute for NABUCCO in which Europe has put its hope for years. TANAP was designed to pass through the same countries as the BTC pipeline, Azerbaijan, Georgia, and Turkey, in order to transit either Bulgaria or Greece to connect to the Trans-Adriatic Pipeline.

The project was first announced at the end of 2011 at the third edition of the Istanbul Black Sea Energy and Economic Forum. The real construction began in March 2015 and its capacity is expected to grow progressively from 10 billion cubic meters to 31 billion cubic meters in 2026. The first deliveries of natural gas through the TANAP pipeline are programmed to be in 2018.

The TANAP gas pipeline alongside the South Caucasus pipeline, also known as BakuTbilisi-Erzurum and the Trans-Adriatic Trans-European pipeline, would form the South Corridor, an ambitious project linking Caspian energy to Europe through Greece, Albania and Italy.

The Trans-Adriatic pipeline is part of the Southern Corridor project and it will have a length of 870 kilometers, allowing more than 10 billion cubic meters of gas to be transported each year, mainly from the Caspian Sea Shah Deniz II source. The construction began officially in May 2016, and it is designed to transit Georgia, Turkey, Greece, Albania and Italy.

The pipeline could supply several countries in south-eastern Europe with gas too, including Bulgaria, Bosnia and Herzegovina, Montenegro and Croatia. Furthermore, if the volume transported to the Western market will be increased as a result of the negotiations with other actors in the Caspian region, such as Iraq, Iran, Turkmenistan or Russia, Caucasian natural gas of could reach markets in Great Britain, France, Switzerland, Germany or Austria. A year after the official start of the works in May 2017, the TAP pipeline seems to be sustainable, and the European Union's desire to bring Caspian gas is closer to its realization.

After the Ukrainian crisis in 2014, the West has become increasingly concerned with the possibility of obtaining energy security. Thus, the states of the European Union have become more and more interested in the fate of the projects in the Caucasus. In this way, the newest and most complex idea has emerged to ensure Europe with up to $20 \%$ more energy independence. The project called the Southern Gas Corridor is designed to connect the Caspian Sea gas to Western Europe on several routes.

The Southern Corridor is currently under construction and consists of four sections: the first is to make extraction from the Shah Deniz basin in Azerbaijan more efficient, the second concerns the pipeline already existing between the cities of Baku and Erzurum. The third concerns the TANAP project, which would link the older pipeline to the Turkish-Greek 
border pipeline. The fourth section of the Southern Corridor consists of the Trans-Adriatic pipeline that is going to connect Greece, Albania and Italy through the Adriatic Sea.

In early 2012, the consortium formed by the project investors decided to go on the Mediterranean route and build the Trans-Adriatic pipeline. TAP project starts in Greece, passes through Albania, and then continues with an offshore part to finally reach Italy.

Southern pipeline transport capacity could be expanded by investing more in the newest technology, but there is a serious problem concerning the resources in the area. More specifically, Azerbaijan alone cannot provide enough gas for Europe to gain its energy security. In order to make this happen, the EU would also need resources from states like Turkmenistan or Iran, but as the status of the Caspian Sea remains uncertain, the possibilities in the area are limited.

As a paradox the Southern Corridor will bring to Europe, also, Russian gas. Europe's high natural gas demand cannot be entirely satisfied by the resources of Azerbaijan or Turkmenistan. Although South Stream was ironically designed to ensure European energy security for the Russian Federation, a Bankwatch report in 2015 drew attention to the fact that the Southern Gas Corridor is not going to be a viable solution. Also, the Oxford Institute for Energy Studies mentioned in a report that Azerbaijan's resources are much lower than originally estimated. However, given that Europe wants to move to a low-carbon economy, the project continues in this direction, ensuring the EU, that its countries can overcome the fossil-fuel based economy.

Because of the fact that countries as Bulgaria, Romania, Hungary or Austria were removed from the main projects, when the companies abandoned the Nabucco project, they decided to build their own transport infrastructure in order to facilitate their access to the highways of natural gas. This is how the BRUA project, named after the initials of each participating state, was born. BRUA was designed to link Central and Eastern Europe to existing projects coming from the Caspian Sea and also to the Black Sea.

In February 2017, the Romanian Minister of Economy signed the document that allowed the beginning of the BRUA project, with a total length on Romanian territory of 550 kilometers and 11 cities crossed. In the context of the latest discoveries in the Black Sea, in Romania the gas pipeline will also have a connection with the technological node in Tuzla.

BRUA should become operational in 2019 when it could transport 4.4 billion cubic meters each year to Hungary. Despite the fact that this project created high expectations at the end of July 2017, the BRUA project was hit by the withdrawal of Hungary. It announced that the state company would no longer build the gas pipeline that should reach Austria, but Hungary is willing to continue the project with the Romanian side. The announcement of the withdrawal has taken by surprise all the states that are involved, but above all Austria, which was also the coordinator of the project. In this new conditions, BRUA could cross either Serbia, Slovakia or Croatia.

Also BRUA project eencountered some problems in Romania, when the National Council for Solving Complaints suspended the tender procedure organized by Transgaz 
made in order to assign the execution contract of the first phase, with a total length of 479 kilometers. The decision was taken as a result of a litigation. Romanian benefits through its involvement in this project are numerous, besides the jobs number involved in such a construction, Romania will make the first important step regarding its desire to become an energetic, stable and solid hub in a very tense area. Furthermore BRUA project perfectly integrates into the regional context and European Union policies of diversifying energy sources as well as securing natural gas supply in an agitated period.

When Nabucco became history, left with no investors, a new idea emerged between Romania, Georgia and Azerbaijan. That to ship gas on the Black Sea. Specifically, there were several discussions of building a gas liquefaction terminal on the Black Sea coast in the Georgian side and another terminal on the Romanian seaside in Constanta for regasification. After this process, the gas would have been taken the west by other means. In 2010 presidents of Romania, Hungary and Azerbaijan signed the first official documents for AGRI interconnection project. At the time they were saying that AGRI is even more effective than Nabucco or South Stream, using the shortest way, the project then was abandoned by all the parts involved. Even if at the beginning of 2015, AGRI was considered an abandoned project, like Nabucco, it has returned to public opinion in recent years, after a several bilateral meetings between the countries involved in the project.

AGRI presents a number of facilities for the transport of Caspian natural gas to the markets of Western Europe. Among the strengths of the project there is the flexibility of LNG technology, which would have transported gas through the Black Sea, the shortest route to the European market. This route could save a lot of kilometers of land pipeline and also the availability of the four states that openly declared their financial support to the AGRI route is a great advantage to take into consideration in the future.

The investment is estimated at 1.2- 4.5 billion euros, depending on the chosen transport capacity. Present in Romania in 2016, the Economic Vice President of SOCAR, declared the Azerbaijan-Georgia-Romania Interconnector is still a feasible project, but it requires a longer period to be prepared given the very high costs involved. Although the group was channeling all its forces to sustain the Baku-Tbilisi-Erzurum gas pipeline, in 2016, Transgaz's president signed a new Memorandum in Baku, along with SOCAR's President. They agreed to provide mutual support in order to increase regional safety regarding natural gas. Although the AGRI project is not specified anywhere in the memorandum, analysts considered that the decision of the two countries to continue their cooperation could be a basis for Romania to reach on the European gas map again.

The AGRI project has an enormous significance for Romania, which in this way would permanently reduce its dependence on Russian gas. Especially regarding the situation in Europe, when several states from Eastern Europe are orienting their domestic policies towards Russia, Romania is still a reliable partner in for NATO, for the US and for the European Union. Neither of the benefits of the seaside regasification terminal should be neglected in a possible analysis of the changes that Romania would benefit from in case AGRI succeeds.

On 21 May 2015 at the Riga Summit, Bulgaria, Romania, Hungary and Slovakia signed a joint statement in favor of the Eastring Gas Pipeline. EGP would bind the southeast of the European continent with the main big pipelines. The pipelines should have 823 kilometers and a capacity of 20 billion cubic meters per year initially, then its capacity could be doubled. The gas pipeline will be built to transport natural gas in bidirectional way. As 
for the direction from south-east Europe to the West, potential gas sources would be Azerbaijan, Turkmenistan, Iraq or Russia, while western European gas would be transported using tanks.

Nowadays the project is at the negotiating stage, which means that in the most optimistic assumption the first transport using Eastring Gas Pipeline could take place in 2020. The Eastring project reaches a total cost of 2 billion euros, and it is from 2015 on the energy priorities top list of the European Union, with the possibility of receiving funding from European programs.

\section{Conclusions}

From the point of view of the force ratio, Russia will remain a hostile player at the eastern border of the European Union. Russia is not willing to make any type of concessions on approaching foreign relations with neighboring states, for which it still has a wish of leading or controlling them, even if not directly. So it is expected that it will continue to use frozen conflicts whenever it feels that the West organizations could directly damage its hegemonic interests.

Kyrgyzstan, Uzbekistan and Tajikistan do not have access to the Caspian Sea and as a result they are heavily dependent on transition trade. In this regard, the main actor in the region is the Russian Federation, which provides them with access to the naval trade. To they are for the moment, trapped.

Azerbaijan, one of the states that intends to further develop its energy transport capacities to Europe, has had a cautious attitude towards the conflict between Russia, Ukraine and the international community. In the sense that it tried to be neutral towards both camps, following its own interest, to see the projects already begun, completed. Gazprom may blackmail Azerbaijani projects, by lowering gas and oil price uncompetitive. In this case Azerbaijan could be brought in a situation in which export would no longer be convenient. In this regard, the Azerbaijan President has stated on several occasions that Azerbaijan's projects for transporting Caspian energy to Europe, are not against Russia, but they come as a result of the state's need to ensure a decent living for its citizens, taking advantage of the country's resources.

However, Russia hasn't had an offensive attitude to the Caspian project launched by Azerbaijan and Turkey for the transportation of Caspian energy in Europe, as evidenced by its attitude towards the settlement of the Caspian Sea legal state, Russia being, on the contrary, one of the states that managed to reach an agreement on the division in the north part of the Caspian Sea. Russia also took important steps at the last Caspian Summit in 2014. TANAP and TAP pipelines do not pose a threat to Russia for many reasons. First, a large quantity of natural gas is going to be used by Turkey, as it negotiated in its posture of transit state. Secondly, the amount of natural gas that Azerbaijan can transport through these projects is too small to strike directly into Russian interests. Europe looks at Caspian resources as a reserve for the Russian side. However they put a lot of hopes in this projects that can bring them a real alternative. But there is also another reason why Russia is not disturbed by the recent Caspian projects in energy, the geographic location of the pipelines, because they are built rather to feed the Balkan and southern European countries and they do not overreach the southern part. This is why the Russian-controlled markets in the European Union, remains for the moment, like they used to be. 
At the same time, for Azerbaijan, the European Union's position is equally important, taking into consideration the fact that the exploitation, exploration and transport of Caspian energy depends on the foreign investors, that are mainly from USA, France, United Kingdom or other high developed countries in Europe. Without their support the most ambitious projects would no longer be sustainable. On the other hand, Caspian countries can help Europe to gain energy security and have more sources of gas and oil from alternative sources, not just from the Russian side. Especially since the giant Gazprom had, over time, a blackmail attitude against those who opposed Russia's position for various reasons. The most important example is that of the war in Ukraine, when Russia used the state-owned Gazprom Company to obtain concessions. This is why, after the annexation of Crimea, the European Union has seriously started looking for alternatives and investing in several pipelines that served transportation of Caspian oil and gas to the West.

The impact of transporting Caspian oil and gas in Europe could be enormous for the European Union, meaning that this main projects and those at different stages of development could really facilitate a degree of independence from Russia's resources. Some of the European countries, such as Germany are heavily dependent on Russia gas, which is not a very comfortable situation for the EU. Europe has high hopes in the basin found just a few hundred kilometers from the Azerbaijani capital, Baku, and Azerbaijan has high hopes of being able to grow economically, as Russia did counting on export of natural resources.

The legal settlement of the Caspian legal status, which is currently uncertain, would represent an even greater step in Europe's attempt to build an alternative to Russian gas. States such as Kazakhstan and Turkmenistan could also become, if the five states would reach an agreement, sources of petroleum, oil and gas for Western states.

In April 2017 the littoral countries managed to have an important agreement about the Caspian Sea's legal status as a result of several "Caspian Dialogue" approaches. Following statements of the Russian Foreign Minister, seamed that the five states would have managed to reach a consensus on the Caspian Sea legal situation. He said, among other things, that the five states decided to refer to the Caspian issue in a harmonious way, so that the national interests of none should not be harmed. The Convention that will ratify once for all the legal status of the Caspian Sea, is already drafted and it is going to be signed by the representatives of the five riparian states at the end of the Fifth Caspian Summit, which is expected to take place shortly. The Russian Foreign Minister's statements were reinforced by the statement of the Ambassador of Kazakhstan in Russia, who said the five states understood that the Caspian Sea is not only a chessboard in the energy game, but a link between the West and the East. The optimism in the area is supported by several recent statements made by various decision-makers among all the Caspian Sea states.

The European Union and the USA want to spread their traditional values such as democracy and human rights, over the Caspian Region, but Iran and Russia consider that Europe's relations with Azerbaijan, Kazakhstan and Turkmenistan can provide not only economic advantages for the EU, but they can also assure a certain control of the region.

For some states, such as Azerbaijan, Turkmenistan and Kazakhstan, solving the Caspian legal issue involves economic issues, while for others, there are also national security positive consequences. This is the case of Russia and Iran which reject any third part existence in the sea. The two, the Russian Federation and Iran, share a common view about the influence of the Americans in the Caspian Sea area, following the Middle East model. 
Often compared with those in the Persian Gulf, Caspian resources are lower than those in the Middle East, but they still are a viable and competitive source for the European market. The only problem is the volatility of the situation in the Caucasian region, characterized by frozen conflicts and tensed interstate relations, often neighbors, such as the Azerbaijan-Armenia relationship. The political and military crises in the area keep economic operators away. The main oil and gas investors are not willing to invest in conflict zones, because there is a high risk of not recovering their money.

The European economy recovered recently after the recession and succeeded in completely overcoming its repercussions, so its needs of gas and oil resources are growing. Comparing the moment when Nabucco was abandoned even because Europe's demand was too low, nowadays Europe's capacity to consume resources at its higher point, hence the need to obtain and strengthen energy security.

In this context, Romania could also have multiple benefits, assuming it remains a reliable partner for Europe and the US, both economically and militarily. The European investors could avoid countries where the internal situation is unstable and choose instead the Romanian transit option. Especially in the conditions of a better relation between Romania and the USA sustained by the visit of the Romanian President, Klaus Iohannis to the White House. If Romania knows how to play it could become a pole of strength in the Eastern Europe. And if Romania understands how to play the book also from an economic point of view, this approach could mean a historic chance. Following a press conference held by the presidents of the two states in 2017, a new type of relationship between Romania and the United States of America was established, a strategic partnership and better bilateral relations. The relationship between the USA, NATO and Romania improved considerably in the sense that Romania has stated one more time its support for the international peacekeeping efforts undertaken by the international community. US President Donald Trump, said that both the US and NATO want a dialogue with Russia, but at the same time they do not agree with its attitude, saying that Russia's discouragement is still desirable.

Romania has managed to obtain European support for the development of projects alongside neighboring countries, such as BRUA, for which the national company Transgaz, has received funding from the European Commission. In this context, we can understand that the European Union, in its integrated energy security process, supports the development of Romania, as a transit country for natural resources. This pipeline could be the main way to transport Caspian gas from the Southern Corridor to the center of Europe and to the former Soviet States in Eastern Europe that need a minimize their dependence on Russian gas. A responsible approach of both the authorities and economic agents involved in the project, could represent a great chance for Romania to strengthen its position as an economic partner for Western Europe, not just a military one.

Apart from BRUA, despite many of the projects that have been talked about, Romania has failed to get involved in the interconnection plans across Europe. Many of the projects targeting Romania have either not materialized or have been in the feasibility study phase for years, have no likely sources of funding or are not cost-effective.

Romania's energy diplomacy in Brussels has, however, succeeded in taking important steps in proving European officials that the state is trustworthy and that it is reforming its energy policies according to the interests of the European community.

Energy security based on solidarity and trust is one of the pillars on which cooperation between EU Member States must be based on in order to identify viable alternative solutions 
in the long run. Diversifying routes, energy sources and suppliers is another opportunity for Romania, as it is geographically located at a strategic point for the EU.

\section{References}

1. Basarabă A. 2007. Aspecte ale geopoliticii resurselor energetice în zona Mării Caspice, despre democratizare în Azerbaidjan în Revista Geopolitica, Asimetria Resurselor Energetice, Top Form, București

2. Brezezinski Z. 1997. Marea tablă de şah, Editura Universul Puterii, București

3. Davor B., Karlo L. 2015. Geopolitical Consequences of Resolving the Legal Status of the Caspian Sea: Security and Energy Aspects

4. Neaç̧u M.C., Neguţ S. 2010. Gas pipelines war în Revista Română de Geoografie Politică, anul XII, nr. 1, Oradea

5. Neacşu M.C., Neguţ S., 2013. Zona Mării Negre-o nouă zonă gri în Strategic Impact, nr. 2, București

6. Neguţ S., 2015. Geopolitica, Meteor Press, București

7. Ougartchinska R, Caree J.M. 2008. Războiul gazelor. Ameninţarea rusă, Antet, Filipeştii de Târg

Revista Geopolitica, Asimetria Resurselor Energetice, Top Form, București

8. Sebille P. 2006. Geopolitiques du petrole, Armand Colin, Paris

9. Troncotă T. 2007. Securitatea resurselor energetice regionale în Caucazul de Sud în Revista Geopolitica, Asimetria Resurselor Energetice, Top Form, București

10. Baku-Tbilisi-Ceyhan (BTC) Pipeline, http://www.bp.com/en_ge/bp-georgia/about-bp/bp-ingeorgia/baku-tbilisi-ceyhan--btc--pipeline.html

11. Baku-Tbilisi-Erzurum Gas Pipeline, http://www.socar.az/socar/en/activities/transportation/bakutbilisi-erzurum-gas-pipeline

12. Cernat F., Conducta BRUA nu va mai traversa teritoriul Ungariei; rute alternative ar putea fi Slovacia, Ucraina, Croația sau Serbia, Agerpres, 27 iulie 2017, https://www.agerpres.ro/economie/2017/07/24/conducta-brua-nu-va-mai-traversa-teritoriul-ungarieirute-alternative-ar-putea-fi-slovacia-ucraina-croatia -sau-serbia-17-25-22

13. Cicovschi A., Incă o piedică în realizarea gazoductului BRUA. Licitaţia organizată de Transgaz a fost contestată, Adevărul.ro, 30 iulie 2017, http://adevarul.ro/economie/investitii/Inca-piedicarealizarea-gazoductului-brua-licitatia-organizata-transgaz-fost-contestata-

1_597ed55d5ab6550cb8a2fe3f/index.html

14. Convention on Caspian Sea Legal Status almost ready for signing, 14 aprilie 2017, https://www.azernews.az/nation/111495.html

15. De Micco P., Changing pipelines, shifting strategies: Gas in south-eastern Europe, Directorate General for External Policies, European Parliament, iulie 2015, http://www.europarl.europa.eu/RegData/etudes/IDAN/2015/549053/EXPO_IDA\%282015\%295490 53_EN.pdf

16. Klare M., Resource Wars: The New Landscape of Global Conflict, Editura Owl Book, New York, 2002 ,

p.102,

https://books.google.ro/books?id=4swk0glJuswC\&dq=Resource+Wars:+The+New+Landscape+of+ Global+Conflict\&hl=ro\&source=gbs_navlinks_s

17. Natural gas consumption statistics, 2016, http://ec.europa.eu/eurostat/statisticsexplained/index.php/Natural_gas_consumption_statistics

18. Timeline of the Baku-Tbilisi-Ceyhan pipeline, iulie 2006, Turkish Daily News, http://www.hurriyetdailynews.com/timeline-of-the-baku-tbilisi-ceyhan-

pipeline.aspx?pageID=438\&n=timeline-of-the-baku-tbilisi-ceyhan-pipeline-2006-07-13

19. Transport Routes Of Azerbaijani Oil (Baku-Novorossiysk, Baku-Supsa), http://www.azerbaijan.az/portal/Economy/OilStrategy/oilStrategy_05_e.html 


\section{5}

